\title{
Mediating Effects of Stakeholders and Supervision on Corporate Social Responsibility
}

http://doi.org/10.21272/bel.4(1).43-56.2020

Fenghua Wang, ORCID: https://orcid.org/0000-0002-9310-9464

$\mathrm{PhD}$, Associate Professor of Accounting, School of Business, Qingdao University, Qingdao, Shandong, China

Janice Lo, ORCID: https://orcid.org/0000-0001-8291-5826

$\mathrm{PhD}$, Assistant Professor of Business Intelligence and Analytics, Heider College of Business, Creighton University, Omaha, Nebraska, USA

Monica Lam, ORCID: https://orcid.org/0000-0002-1205-1302

$\mathrm{PhD}$, Professor of Management Information Systems, College of Business, University of Central Oklahoma, Edmond, Oklahoma, USA

\begin{abstract}
The deficit of mineral resources, the aggravation of environmental problems in the world, the decrease in nonrenewable resources determined the increasing role of the responsibility of enterprises for the direct and indirect impact on the economic, environmental and social systems of their functioning. The systematization of scientific work in the field of corporate social responsibility showed the lack of comprehensive studies concerning the nature and strength of the impact of direct and latent factors on enterprises' compliance with the principles of corporate social responsibility. In this research study, we hypothesized that the common contributing factors for corporate social responsibility benefits in the literature such as institutional pressures, market/societal pressures, and structural support are mediated by the factors of stakeholder influence and supervision effect. The data from an empirical survey of 334 corporate executives were collected to test our hypotheses of mediating effects. The partial least squares structural equation modelling (PLS-SEM) approach was used to test the 11 hypotheses from the research model. The research model is statistically significant with an explanatory power of $R^{2}=0.468$ for the dependent variable CSR benefits. The statistical results show that the direct effects of the three common contributing factors to CSR are not significant. All the standardized path coefficients $(\beta)$ of direct effects from institutional pressures, market/societal pressures, and structural support to corporate social responsibility benefits are less than 0.1 . On the other hand, their effects are significant through the mediating factors of stakeholder influence and supervision. If we characterize stakeholder influence as words and supervision effect as deeds, then words are more significant than deeds (the path coefficient from supervision effect to corporate social responsibility benefits is 0.243 , while from stakeholder influence to corporate social responsibility benefits is 0.443 ). Moreover, if we characterize external pressures as a stick and structural support as carrot, our research results show that stick $(0.413$ for market/societal pressures, 0.387 for institutional pressures) is more significant than the carrot $(0.115)$ in effectuating corporate social responsibility benefits.
\end{abstract}

Keywords: Corporate Social Responsibility, Stakeholders, Supervision, Mediating Effect, Factors of Influence.

\section{JEL Classification: M14.}

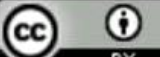

Cite as: Wang, F., Lo, J., Lam, M. (2020). Mediating Effects of Stakeholders and Supervision on Corporate Social Responsibility. Business Ethics and Leadership, 4(1), 43-56. http://doi.org/10.21272/bel.4(1).4356.2020.

(C) The Authors, 2020. This article is published with open access at Sumy State University.

\section{Introduction}

In the midst of financial crises, corporate faults, data breaches, climate changes, environmental impacts, ecological imbalances, the concept of corporate social responsibility (CSR) has become one of the most 
important research topics in the past decade. Earlier CSR research focused on what a company should do in order to be considered as carrying out social responsibilities. Lately, the attention turns to the relationships among different factors in CSR models in different cultural and industrial contexts. Those factors that have been studied extensively include competitive advantage, financial performance, company reputation, leaders' values, employee satisfaction, religious influence, external pressure, structural support, and others. In this study, we are especially interested in the mediating effect of stakeholders and supervision between the independent factors of institutional pressures, market and societal pressures, structural support and the dependent factor of CSR benefits. Being a legal entity, an organization's soul and action are shaped by those people who represent or are affected by the organization, i.e., stakeholders. Moreover, we believe that the supervision environment in which the stakeholders are operating also has a significant effect on the CSR benefits.

CSR is the good citizenship behaviour of an organization that contributes to overall wellbeing, sustainable development, environmental protection, and righteousness in society. We adopt the refined definition of CSR by the International Organization for Standardization as the responsibility of an organization for the impacts of its decisions and activities on society and environment through transparent and ethical behaviour including contributing to maintainable development, meeting the expectations of stakeholders, obeying applicable law, and being consistent with international norms of behaviour (ISO, 2010). In a nutshell, there are three basic dimensions of economics, ethics, and legality for CSR goals (Schwartz \& Carroll, 2003). In terms of CSR responsibilities, the ISO scheme includes the five areas of employee, business, environment, governance, and public interest. The rest of this paper covers a literature review, conceptual modelling of the research questions, research hypotheses, research methodology, statistical analysis, discussion, and conclusion.

\section{Literature Review}

The literature has suggested many CSR benefits including financial performance, competitive advantage, company image and reputation, risk management, employee satisfaction, and stakeholder relationship (Fanghui \& Ziyuan, 2005; Wayne \& Chad, 2015; Brekke \& Nyborg, 2005; Aya Pastana \& Sriramesh, 2014; Chunfang, 2009; Yibo, 2007). Regarding CSR drivers, environmental pressure is often cited as a significant factor leading to CSR behaviour. McKinley's study in 2008 identified legal constraints, government regulation, risk management, industry standards, reputation management, ethical consumerism, non-governmentalorganization (NGO) action, the pressure of employee and investors, and environmental and social factors as important drivers for CSR (McKinley, 2008). Similarly, the Economic Commission for Latin American and the Caribbean found that system pressure, company image, employee satisfaction, competitive advantage, and community commitment are the main drivers for CSR (ECLAC, 2008). Specifically, external pressure can be from laws and legal establishment (Susan \& Mona, 2014; Mzembe \& Meaton, 2014; Zhilong \& Yuanqiong, 2005; Taisong 2013), government and audits (Zhilong \& Yuanqiong, 2005; Chunyang, 2009), international purchaser (Roy \& Vigao, 2013), competitors (Aya Pastrana \& Sriramesh, 2014; ECLAC, 2008), consumer and public media (McKinley, 2008; Chunfang, 2009), and international norms of social responsibility (McKinley, 2008; Mzembe \& Meaton, 2014).

While CSR pressure can come from institution, market, or society, research studies also look at the board of directors, disclosure requirements, and other structural mechanisms as possible drivers for CSR. Jackson et al. (2019) investigated the relationship between government regulation and CSR. While they found that firms in countries that require non-financial disclosure have more CSR activities, the non-financial disclosure regulation has no effect on reducing corporate irresponsibility. The relationship between structural pressure and CSR does not seem to be consistent. Using a sample of French listed companies in 2010-2013, Ajina et al. (2018) showed that independent boards and high institutional ownership structure can lead to a strong effect of CSR on earnings management. Garas \& ElMassah (2018) studied 147 firms in the Gulf Cooperation Council countries. They also found that internal corporate governance mechanisms such as the independence of board members and audit committee, as well as the separation of powers between the CEO and chairman, have a positive effect on CSR disclosure. Bice (2017) introduced the concept of CSR as an institution that can be defined as formal and informal pressures exercised on actors by key stakeholders, including other organizations and communities, reflecting societal expectations and rules. This definition highlights the importance of stakeholders and pressures in the understanding of CSR. Atherton et al. (2011) argued that the concept of the fiduciary is both a societal and a legal principle. The application of ethical and fiduciary duties through stakeholders and the greater community can provide more socially responsible guidelines for corporations in 
the environment of increased government regulation. In other words, legal pressure from the environment and stakeholders' influence are related and should not be dealt with separately.

Though it seems logical to expect that sensitive industry sectors such as those concern about product safety and environmental impact will pay attention to CSR assurance, Sethi et al. (2017) did not find evidence to support that. On the other hand, they found that code-law countries are associated with higher CSR assurance rates and better CSR quality assurance statements. Their orientation towards broader stakeholders than merely proximal shareholders leads to more credible CSR disclosures. This study points to the positive relationship between stakeholder orientation and CSR sensitivity. Jose-Luis et al. (2018) concluded that the existence of a board sub-committee for CSR, its size, the term limit for independent directors, and directors' receiving external advice positively relate to CSR engagement. This study extended the understanding of the relationship between stakeholders and CSR by looking into the detailed nature of stakeholders' activities and how they affect CSR. Regarding boards and audit committees being a stakeholder, Katmon et al. (2019) investigated the effect of board diversity on CSR disclosure. They found a significant positive effect of education level, tenure diversity, and gender diversity but a negative effect of age and nationality diversity on the quality of CSR disclosure.

We next review studies on stakeholders, supervising, auditing, and CSR in the literature. Per Freeman (1984), stakeholders are all entities on whom an organization's performance and actions have some influence. Camilleri (2017) reviewed how the stakeholder management theory can link CSR with corporate financial performance. It was suggested that CSR can create economic and societal value when stakeholder and environment are taken into consideration of corporate objectives. As shown by Carroll and Shabana (2010), organizations create long term value to society when they proactively and respectfully satisfy their stakeholders by fulfilling their economic, legal, and ethical responsibilities. On the other hand, Lisi (2018) concluded that perceived stakeholder concern has no significant effect on the use of social performance indicators while expected competitive advantage and top management's social commitment have such significant effect. In Wang and Liang's study (2017) of 468 Chinese private firms, the stakeholders are divided into four groups of employees, customers, communities, and environment. Employees and customers are classified as economic stakeholders while communities and environment are classified as social stakeholders. They found that social stakeholders are more important than economic stakeholders in CSR consideration when the percentage of family ownership is higher, an initial public offering is imminent, and firm size is smaller. In addition to recognizing the importance of stakeholders' influence on CSR, this study went one step further of looking into the differential effects on CSR from two categories of stakeholders.

Vashchenko (2017) suggested both the stakeholder perspective and institutional perspective as two shaping forces for governmental-related, business-related, and society-related pressure on CSR behaviour. The stakeholder perspective includes local government, national government, global government, government and business stakeholders, institutional investors, consumers, buyers, suppliers, business partners, professional associations, competitors, NGOs, social movement organizations, media, academic networks, and universities. The institutional perspective includes laws, policies, voluntary agreements, macroeconomic forces, business interests and values, market power, business norms, shared beliefs, and educational norms. This model has stakeholder and institutional factor as two concurrent or equal drivers determining the CSR decisions. Sanchez (2017) showed that stakeholder pressure directly impacts how CSR policies are applied by public managers in dealing with suppliers for their organization's benefit. Though this study is limited to the business function of supply-chain management, the role of stakeholders in determining CSR's benefit to an organization is catching investigators' attention. In another regression analysis study, Zhao et al. (2016) concluded that the relationship between managers' attention to social issues and corporate social performance was moderated by governance mechanisms that constrain managerial discretion in a Chinese firm context. This study sheds light on the inbetween role of stakeholders' governance. Smolennikov and Kostyuchenko (2017) developed a comprehensive conceptual model for the interrelationship and mutual influence between corporate social/environmental responsibility and different stakeholders in social and economic transformation.

Overall, Shubham \& Murty (2018) asked an important question considering many studies proclaiming the significant drivers of environmental pressures, structural mechanisms, stakeholders, and supervision for CSR. The question is why the same institutional pressure leads to different environmental practices. Their answer lies with the mediating role of absorptive capacity in knowledge management. This strategy pointed us to the direction of identifying effective mediators between drivers and CSR. The study of Burt and Mansell (2017) provided further insight into our pursuit of effective mediators. They suggested that a business corporation 
does not possess a soul or conscience leading to CSR. It is only through the members of a business corporation for it to exhibit socially conscious behaviour. Kurbjeweit (2011) advanced this understanding by suggesting that legal regulations do not sustain the orderly function of society without ethical business actors. Following this line of logic, there is reason to believe that stakeholders and their supervision activities are significant mediators between CSR drivers and CSR benefits in a business corporation. The next section will elaborate on the conceptual modelling of the research objectives in this study.

\section{Conceptual Modeling and Research Hypotheses}

We attempt to answer two basic research questions in this study. First, do institutional pressures, market and societal pressures, and structural supports have a significant effect on stakeholders and their supervision for determining CSR benefits? Second, in the process above, do stakeholders and their supervision have a significant mediating effect on CSR benefits? Figure 1 shows the full conceptual model in this research study. Table 1 lists the variables we identified from the literature contributing to the factors in the conceptual model. This conceptual model addresses a few gaps in the current CSR literature. First, though stakeholders have been identified as influential in determining CSR, they usually are treated similarly as the factors of institutional pressure, market demand, and social demands rather than a mediating factor (Vashchenko, 2017). The research model in this study is specially designed to determine the mediating effect of stakeholders. Second, if the stakeholders of an organization represent its soul, stakeholders' supervision can be understood as the soul's manifestation. The research model has supervision effect as the second mediating factor leading to the ultimate factor of CSR benefits. Our literature review has not identified a research model in CSR that incorporates both stakeholders and their supervision as the mediating factors. Third, while many CSR research models include many factors to increase their explanatory capacity, the research model in this study focuses on only the institutional pressure, market \& societal pressures, and structural support, three exogenous factors; stakeholders and supervision, two mediating factors; and CSR benefits as the endogenous factor. The simple conceptual model provides a succinct explanation path to CSR determination. Fourth, the empirical survey in this study captured a wide spectrum of companies in terms of size, industrial sector, and ownership, as well as a group of highly diversified respondents, which enhances the generalizability power of the research results than many other studies that are based on only one industry, one company, or one demographic group. Please see Table 2 for the characteristics of companies in the survey, and Table 3 for the demographic characteristics of survey respondents.

As illustrated in the research model in Figure 1, the first set of hypotheses states that the three exogenous factors - institutional pressure, market and societal pressure, and structural support - are all positively associated with both stakeholder influence and supervision effect. We state these formally as:

H1: Institutional Pressure is positively associated with Stakeholder Influence.

H2: Institutional Pressure is positively associated with Supervision Effect.

H3: Market \& Societal Pressure is positively associated with Stakeholder Influence.

H4: Market \& Societal Pressure is positively associated with Supervision Effect.

H5: Structural Support is positively associated with Stakeholder Influence.

H6: Structural Support is positively associated with Supervision Effect.

The second set of hypotheses states that stakeholder influence and supervision effect are both positively associated with CSR benefits. We state these hypotheses formally as:

H7: Stakeholder Influence is positively associated with CSR Benefits.

H8: Supervision Effect is positively associated with CSR Benefits.

The third set of hypotheses states that stakeholder influence and supervision effect mediate the effects of the exogenous factors on CSR benefits. These are stated formally as:

H9: The association between Institutional Pressures and CSR Benefits will be at least partially mediated by Stakeholder Influence and Supervision.

H10: The association between Market \& Societal Pressures and CSR Benefits will be at least partially mediated by Stakeholder Influence and Supervision. 
H11: The association between Structural Support and CSR Benefits will be at least partially mediated by Stakeholder Influence and Supervision.

We also predict that stakeholders' supervision is more important than their promotion. It is because we believe action is more influential than talk. Therefore, the mediating effect of supervision should be stronger than the mediating effect of stakeholder influence.

Table 1. Variables in Factors

\begin{tabular}{|c|c|c|}
\hline Factor & Variables & References \\
\hline CSR Benefits & $\begin{array}{l}\text { - Enhancing company image or reputation } \\
\text { - Strengthening the company's competitive advantage } \\
\text { - Improving the company's financial performance } \\
\text { - Attracting or retaining employees } \\
\text { - Improving customers' loyalty } \\
\text { - Reducing operational risks } \\
\text { - Facilitating relationships with stakeholders } \\
\text { - Cultivating a good organizational culture } \\
\text { - Promoting the sustainable development of the company }\end{array}$ & $\begin{array}{l}\text { McKinley \& Andrew (2008); ECLAC (2008); } \\
\text { Zhilong \& Yuanqiong (2005); Aya Pastrana \& } \\
\text { Sriramesh (2014); Fanghui \& Ziyuan (2005); } \\
\text { Wayne \& Chad (2015); Brekke \& Nyborg } \\
\text { (2005); Chunfang (2009); Ankur Roy \& Vishal } \\
\text { (2013); Susan \& Mona (2014) }\end{array}$ \\
\hline $\begin{array}{l}\text { Institutional } \\
\text { Pressures }\end{array}$ & $\begin{array}{l}\text { - Pressures from laws and institutions } \\
\text { - Pressures from government and supervisors } \\
\text { - Pressures from international purchasers }\end{array}$ & $\begin{array}{l}\text { McKinley \& Andrew (2008); ECLAC (2008); } \\
\text { Susan \& Mona (2014); Mzembe \& Meaton } \\
\text { (2014); Zhilong \& Yuanqiong (2005); Taisong } \\
\text { (2013); Ankur Roy \& Vishal (2013); Hongling } \\
\text { (2006) }\end{array}$ \\
\hline $\begin{array}{l}\text { Market and } \\
\text { Societal } \\
\text { Pressures }\end{array}$ & $\begin{array}{l}\text { - The reputation in the labour market and capital market } \\
\text { - Pressures from competitors } \\
\text { - Social pressures from consumers, media, etc. } \\
\text { - Religious influence [dropped] } \\
\text { - Pressure from international norms of social } \\
\text { responsibility }\end{array}$ & $\begin{array}{l}\text { McKinley \& Andrew (2008); ECLAC (2008); } \\
\text { Susan \& Mona (2014); Mzembe \& Meaton } \\
\text { (2014); Zhilong \& Yuanqiong (2005); Taisong } \\
\text { (2013); Ankur Roy \& Vishal (2013); Hongling } \\
\text { (2006) }\end{array}$ \\
\hline Stakeholders & $\begin{array}{l}\text { - Shareholders [dropped] } \\
\text { - Employees } \\
\text { - Suppliers, customers, and other business partners } \\
\text { - Competitors } \\
\text { - Company's leaders [dropped] } \\
\text { - Governments and regulators [dropped] } \\
\text { - Community } \\
\text { - Non-governmental organization } \\
\text { - Public media }\end{array}$ & $\begin{array}{l}\text { Roy \& Vigao (2017); Sanchez (2017); Zhao et } \\
\text { al. (2016); Freeman (1984); Camilleri (2017); } \\
\text { Carroll \& Shabana (2010); Lisi (2018); Wang } \\
\& \quad \text { Liang (2017); Smolennikov \& } \\
\text { Kostyuchenko (2017) }\end{array}$ \\
\hline Supervision & $\begin{array}{l}\text { - Internal supervision of the company } \\
\text { - Market supervision from supply chain } \\
\text { - Capital market supervision } \\
\text { - Government supervision } \\
\text { - Social supervision from public media, independent } \\
\text { organizations, etc. } \\
\text { - Audit supervision from an independent third party }\end{array}$ & $\begin{array}{l}\text { Vashchenko (2017); Sanchez (2017) Zhao et al. } \\
\text { (2016); Shubham \& Murty (2018); Burt \& } \\
\text { Mansell (2017); Kurbjeweit (2011) }\end{array}$ \\
\hline $\begin{array}{l}\text { Structural } \\
\text { Support }\end{array}$ & $\begin{array}{l}\text { - Social responsibility department } \\
\text { - Social responsibility management system } \\
\text { - Someone responsible for social responsibility issues in } \\
\text { the board of directors or management } \\
\text { - CSR as a criterion for selecting business partners } \\
\text { - The social responsibility evaluation system } \\
\text { - Social responsibility supervisory mechanism } \\
\text { - Membership in international organizations of social } \\
\text { responsibilities }\end{array}$ & $\begin{array}{l}\text { Jackson et al. (2019); Ajina et al. (2018); Bice } \\
\text { (2017); Atherton et al. (2011); Sethi et al. } \\
\text { (2017); Jose-Luis et al. (2018) }\end{array}$ \\
\hline
\end{tabular}

Source: Compiled by authors 
Table 2. Company Characteristics in Survey

\begin{tabular}{|c|c|c|}
\hline Characteristic & Category & $\%$ \\
\hline \multirow{3}{*}{$\begin{array}{l}\text { Number } \\
\text { Employees }\end{array}$} & Less than 300 & $29 \%$ \\
\hline & $300-1000$ & $18 \%$ \\
\hline & 1000 or over & $53 \%$ \\
\hline \multirow{15}{*}{ Industrial Sector } & Agriculture, Forestry, Fishing and Hunting & $2 \%$ \\
\hline & Mining, Oil and Gas Extraction & $5 \%$ \\
\hline & Utilities & $5 \%$ \\
\hline & Construction & $2 \%$ \\
\hline & Manufacturing & $19 \%$ \\
\hline & Wholesale and Retail Trade & $5 \%$ \\
\hline & Transportation and Warehousing & $2 \%$ \\
\hline & Information & $4 \%$ \\
\hline & Finance and Insurance & $13 \%$ \\
\hline & Health Care and Social Assistance & $7 \%$ \\
\hline & Public Administration & $4 \%$ \\
\hline & Real Estate and Rental and Leasing & $2 \%$ \\
\hline & Professional, and Technical Services & $6 \%$ \\
\hline & Educational Services & $7 \%$ \\
\hline & Other & $15 \%$ \\
\hline \multirow{5}{*}{ Company Ownership } & State-owned Enterprises & $27 \%$ \\
\hline & Private Enterprises & $39 \%$ \\
\hline & Foreign-capital Enterprises & $8 \%$ \\
\hline & Mixed-ownership Enterprises & $9 \%$ \\
\hline & Other & $18 \%$ \\
\hline
\end{tabular}

Source: Compiled by authors

Table 3. Survey Respondent Characteristics

\begin{tabular}{|c|c|c|}
\hline Characteristic & Category & $\%$ \\
\hline \multirow{2}{*}{ Gender } & Male & $62 \%$ \\
\hline & Female & $38 \%$ \\
\hline \multirow{4}{*}{ Age } & Less than 35 & $54 \%$ \\
\hline & 36 to 40 & $20 \%$ \\
\hline & 41 to 45 & $11 \%$ \\
\hline & 46 or over & $15 \%$ \\
\hline \multirow{4}{*}{ Education } & Doctoral Degree & $3 \%$ \\
\hline & Master's Degree & $67 \%$ \\
\hline & Bachelor's Degree & $29 \%$ \\
\hline & Associate Degree & $1 \%$ \\
\hline \multirow{6}{*}{ Major } & Economics & $6 \%$ \\
\hline & Management & $63 \%$ \\
\hline & Engineering & $9 \%$ \\
\hline & Science & $3 \%$ \\
\hline & Laws & $1 \%$ \\
\hline & Other & $18 \%$ \\
\hline \multirow{6}{*}{ Job Title } & Chairman or CEO & $4 \%$ \\
\hline & Vice President & $6 \%$ \\
\hline & Director & $5 \%$ \\
\hline & Manager or Supervisor & $34 \%$ \\
\hline & Administrator & $17 \%$ \\
\hline & Other & $33 \%$ \\
\hline \multirow{5}{*}{ Knowledge of CSR } & Very Little & $6 \%$ \\
\hline & Little & $16 \%$ \\
\hline & Medium & $47 \%$ \\
\hline & Much & $26 \%$ \\
\hline & Very Much & $4 \%$ \\
\hline \multirow{3}{*}{ Religious belief } & Yes & $34 \%$ \\
\hline & No & $58 \%$ \\
\hline & Not sure & $8 \%$ \\
\hline
\end{tabular}

Source: Compiled by authors 


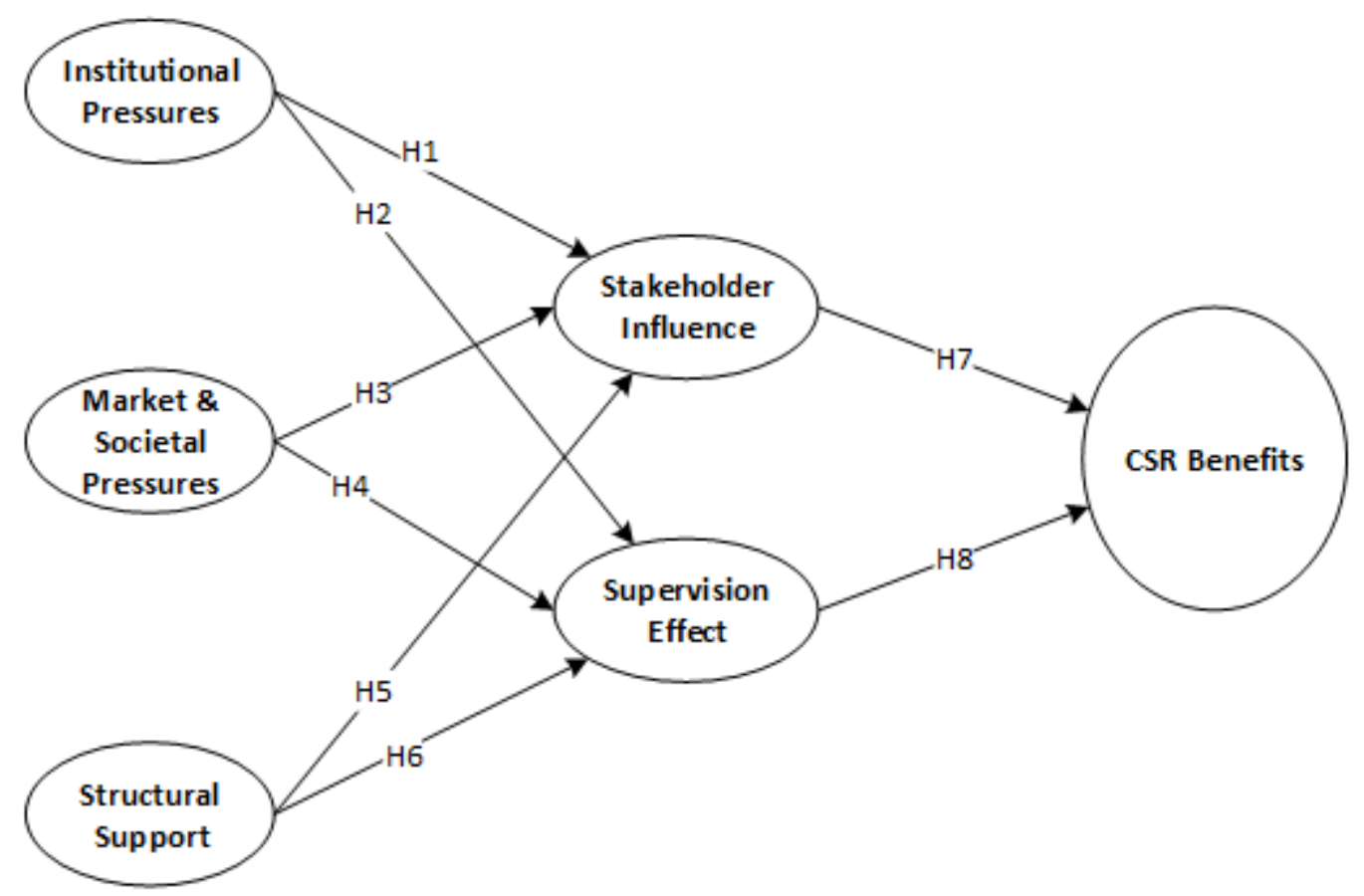

Mediation Hypotheses

H9: The association between Institutional Pressures and CSR Benefits will be at least partially mediated by Stakeholder Influence and Supervision.

H10: The association between Market \& Societal Pressures and CSR Benefits will be at least partially mediated by Stakeholder Influence and Supervision.

H11: The association between Structural Support and CSR Benefits will be at least partially mediated by Stakeholder Influence and Supervision.

Source: Compiled by authors

Figure 1. Full Conceptual Model for CSR

\section{Research Methodology}

We adopted the research methodology of an in-depth interview and empirical survey to address our research questions. For the variables in Table 1, we invited respondents to evaluate the importance of each variable for CSR in their organizations using the Likert scale of 1-5 with 5 being the most important. For measuring structural support, respondents were asked about the existence of the structural support items at their companies, and the possible responses for this question were Yes, No, and Do Not Know. As the first step, seven experts in the area of CSR including four professors and three senior managers were interviewed to discuss the importance of the variables. The interviews provided feedback regarding the coverage, relevancy, accuracy, and understandability of the variables of CSR. In addition, the experts assessed whether the questionnaire design is sufficient to achieve the purpose of the investigation. The results of the interviews preliminarily confirmed the validity and relevancy of the twenty-three variables. Next, we administered a pretest to fifteen senior managers. Based on the results of the pretest, the wording of some variables was modified to enhance their understandability. The final questionnaire consists of the basic information of respondents, basic information of companies, and the importance evaluation of variables for CSR.

\section{Sample and Data}

This study selected the middle to senior managers of companies, as well as MBA and Executive MBA students in the investigators' industrial and education networks as the sample population. As MBA and EMBA students generally come from middle to senior management in organizations, they are considered as an appropriate sample population for this study. Qualtrics was used to execute the Web survey. An invitation email was sent to the survey population, followed by two email reminders. To motivate survey participation, there was a charity donation of US $\$ 10.00$ per completed survey to an organization of the respondent's choice. The survey was held over a period of 40 days, from June to July 2015. The sample population has a total of 2763 people. After two email reminders, a total of 465 surveys were returned. The initial response rate is $16.8 \%$. After eliminating incomplete surveys, there were a total of 334 usable surveys for the final analysis. The usable response rate is $12.1 \%$. The descriptive statistics about the respondents and their companies are shown in Table 
2 and Table 3 respectively. The characteristics distribution of the respondents and companies do not cause concerns for the data analysis in this research.

\section{Measures}

All measures for this study were modelled as reflective measures. Structural support, however, was measured using a single-item scale due to the nature of the question and the possible responses of Yes, No, and Do Not Know. We calculated the single-item measure representing structural support by taking the sum of all Yes responses for each respondent and subtracting from it the sum of all No responses. This resulting measure would then represent the degree of structural support for CSR at a company.

\section{Statistical Analysis and Results}

\section{Bias Checks and Control Variables}

To test for common method bias, we conducted a Lindell and Whitney (2001) test using a theoretically unrelated variable, called a "marker" variable. Following Pavlou et al. (2007), we used a weakly related variable, in this case, the respondent's education level. The test showed low correlations between the respondent's education level and the model's constructs, with the average correlation being $r=0.09$, indicating minimal evidence of common method bias. In addition, the correlation matrix in Table 4 does not indicate any highly correlated factors. Whereas extremely high correlations of above 0.90 would indicate evidence of common method bias (Pavlou et al., 2007), the table shows that the highest correlation is 0.65 .

Control variables were also tested prior to analyzing the research model to determine whether any were significant predictors of CSR benefit, the dependent variable. Variables tested include respondents' age, education level, whether or not the respondent has religious faith, the length of time the respondent's company has been established, and the number of employees working in the company. None of these control variables was found to be significant predictors of CSR benefit.

\section{Measurement Model}

The partial least squares structural equation modelling (PLS-SEM) approach was used to examine the model due to the exploratory nature of this study. When examining a research model, PLS-SEM focuses on explaining the variance of the dependent variables, that is, prediction of the constructs (Hair et al., 2017). It is thus better suited for exploratory research and developing theories (Hair et al., 2017). The research model was analyzed using SmartPLS 3 (Ringle et al., 2014).

The measurement model was assessed for convergent validity, internal consistency reliability, and discriminant validity. For convergent validity, the item loadings were above 0.60 and the average variance extracted (AVE) were above 0.50 , which indicate acceptable convergent validity of the factors (Hair et al., 2017). See Table 5. For internal consistency reliability, the composite reliability (CR) measures were greater than 0.70 (Chin, 1998) and the Cronbach's Alpha is greater than 0.60 (Hair et al., 2014), indicating acceptable internal consistency. See Table 5. For discriminant validity, the square root of the AVE for each factor was higher than the correlations with other factors, indicating that each factor shares higher variance with items in its own factor than with items in other factors (Chin, 1998; Fornell and Larcker, 1981). See Table 4. In addition, the Heterotrait-Monotrait Ratio (HTMT) (Henseler et al., 2015) of the correlations was tested. HTMT is an estimate of "what the true correlation between two constructs would be if they were perfectly measured" (Hair et al., 2017: 118). A ratio of close to 1 would indicate a lack of discriminant validity. The HTMT values for this study were below the conservative threshold of 0.85 and the values are significantly different from 1, thus indicating acceptable discriminant validity (Hair et al., 2017). See Table 5. To facilitate the reliability and validity of the measurement model, several items as indicated in Table 1 were dropped.

Table 4. Construct Correlations and Fornell-Larcker Criterion for Assessing Discriminant Validity

\begin{tabular}{|l|r|r|r|r|r|r|}
\hline & $\begin{array}{c}\text { CSR } \\
\text { Benefits }\end{array}$ & $\begin{array}{c}\text { Institutional } \\
\text { Pressures }\end{array}$ & $\begin{array}{c}\text { Market \& } \\
\text { Societal } \\
\text { Pressures }\end{array}$ & $\begin{array}{c}\text { Stakeholder } \\
\text { Influence }\end{array}$ & $\begin{array}{c}\text { Structural } \\
\text { Support }\end{array}$ & Supervision \\
\hline CSR Benefits & 0.7540 & & & & & \\
\hline Institutional Pressures & 0.3100 & 0.8250 & & & & \\
\hline Market \& Societal Pressures & 0.4220 & 0.5790 & 0.7800 & & & \\
\hline Stakeholder Influence & 0.6450 & 0.3170 & 0.4850 & 0.7300 & & \\
\hline Structural Support & 0.2090 & 0.0710 & 0.2690 & 0.2300 & 1.0000 & \\
\hline Supervision & 0.5530 & 0.5040 & 0.4340 & 0.6060 & 0.1170 & 0.7440 \\
\hline
\end{tabular}

Note: The diagonal shaded cells are the square roots of the average variance extracted (AVE) for each factor.

Source: Compiled by authors 
Table 5. Summary Results of Measurement Reliability and Validity

\begin{tabular}{|c|c|c|c|c|c|c|}
\hline \multirow[b]{2}{*}{$\begin{array}{c}\text { Latent } \\
\text { Variables }\end{array}$} & \multirow[b]{2}{*}{ Indicators } & \multicolumn{2}{|c|}{ Convergent Validity } & \multicolumn{2}{|c|}{$\begin{array}{c}\text { Internal Consistency } \\
\text { Reliability }\end{array}$} & \multirow{2}{*}{$\begin{array}{c}\begin{array}{c}\text { Discriminant } \\
\text { Validity }\end{array} \\
\text { HTMT } \\
\text { Confidence } \\
\text { Internal Does } \\
\text { Not Include 1 }\end{array}$} \\
\hline & & Loadings & AVE & $\mathbf{C R}$ & $\begin{array}{c}\text { Cronbach's } \\
\text { Alpha }\end{array}$ & \\
\hline \multirow{9}{*}{ CSR Benefits } & CSRBenefits_1 & 0.643 & \multirow{9}{*}{0.568} & \multirow{9}{*}{0.922} & \multirow{9}{*}{0.905} & \multirow{9}{*}{ Pass } \\
\hline & CSRBenefits_2 & 0.767 & & & & \\
\hline & CSRBenefits_3 & 0.748 & & & & \\
\hline & CSRBenefits_4 & 0.749 & & & & \\
\hline & CSRBenefits_5 & 0.793 & & & & \\
\hline & CSRBenefits_6 & 0.759 & & & & \\
\hline & CSRBenefits_7 & 0.782 & & & & \\
\hline & CSRBenefits_8 & 0.741 & & & & \\
\hline & CSRBenefits_9 & 0.792 & & & & \\
\hline \multirow{3}{*}{$\begin{array}{l}\text { Institutional } \\
\text { Pressures }\end{array}$} & PressuresInstitutional_1 & 0.865 & \multirow{3}{*}{0.680} & \multirow{3}{*}{0.863} & \multirow{3}{*}{0.756} & \multirow{3}{*}{ Pass } \\
\hline & PressuresInstitutional_2 & 0.899 & & & & \\
\hline & PressuresInstitutional_3 & 0.695 & & & & \\
\hline \multirow{4}{*}{$\begin{array}{l}\text { Market } \quad \& \\
\text { Societal } \\
\text { Pressures }\end{array}$} & PressuresMarketSocietal_1 & 0.807 & \multirow{4}{*}{0.608} & \multirow{4}{*}{0.861} & \multirow{4}{*}{0.787} & \multirow{4}{*}{ Pass } \\
\hline & PressuresMarketSocietal_2 & 0.809 & & & & \\
\hline & PressuresMarketSocietal_3 & 0.714 & & & & \\
\hline & PressuresMarketSocietal_5 & 0.785 & & & & \\
\hline \multirow{6}{*}{$\begin{array}{l}\text { Stakeholder } \\
\text { Influence }\end{array}$} & StakeholderInflu_2 & 0.620 & \multirow{6}{*}{0.533} & \multirow{6}{*}{0.872} & \multirow{6}{*}{0.823} & \multirow{6}{*}{ Pass } \\
\hline & StakeholderInflu_3 & 0.772 & & & & \\
\hline & StakeholderInflu_4 & 0.768 & & & & \\
\hline & StakeholderInflu_7 & 0.779 & & & & \\
\hline & StakeholderInflu_8 & 0.780 & & & & \\
\hline & StakeholderInflu_9 & 0.643 & & & & \\
\hline \multirow{6}{*}{ Supervision } & Supervision_1 & 0.617 & \multirow{6}{*}{0.554} & \multirow{6}{*}{0.881} & \multirow{6}{*}{0.836} & \multirow{6}{*}{ Pass } \\
\hline & Supervision_2 & 0.810 & & & & \\
\hline & Supervision_3 & 0.816 & & & & \\
\hline & Supervision_4 & 0.710 & & & & \\
\hline & Supervision_5 & 0.782 & & & & \\
\hline & Supervision_6 & 0.710 & & & & \\
\hline
\end{tabular}

Source: Compiled by authors

\section{Structural Model and Mediation Analysis}

A bootstrap resampling procedure of 5000 subsamples was used to test the significance of the structural research model. Figure 2 illustrates the overall model results from the structural analysis, with explanatory powers $\left(R^{2}\right)$ and standardized path coefficients $(\beta)$. In this figure, the direct relationships between the exogenous variables - institutional pressures, market and societal pressures, and structural support - and the dependent variable CSR benefits were included to illustrate the non-significance of these direct relationships in the presence of the mediation hypotheses, which will be tested next. The results for Hypotheses 1 through 8 show that 6 of the 8 hypotheses were supported. Institutional pressures, market and societal pressures, and structural support accounted for $25 \%$ of the variance in stakeholder influence and $28.5 \%$ of the variance in supervision effect. Stakeholder influence and supervision effect, along with the three exogenous variables, accounted for $47 \%$ of the variance in CSR benefits, though the direct effects of the exogenous variables on CSR benefits were all non-significant. Without the exogenous variables, stakeholder influence and supervision effect by themselves account for $46 \%$ of the variance in CSR benefits, which suggests that in the presence of the two mediating factors, the exogenous factors are negligible in directly explaining CSR benefits. This appears to support the mediation hypotheses, which is tested next. 


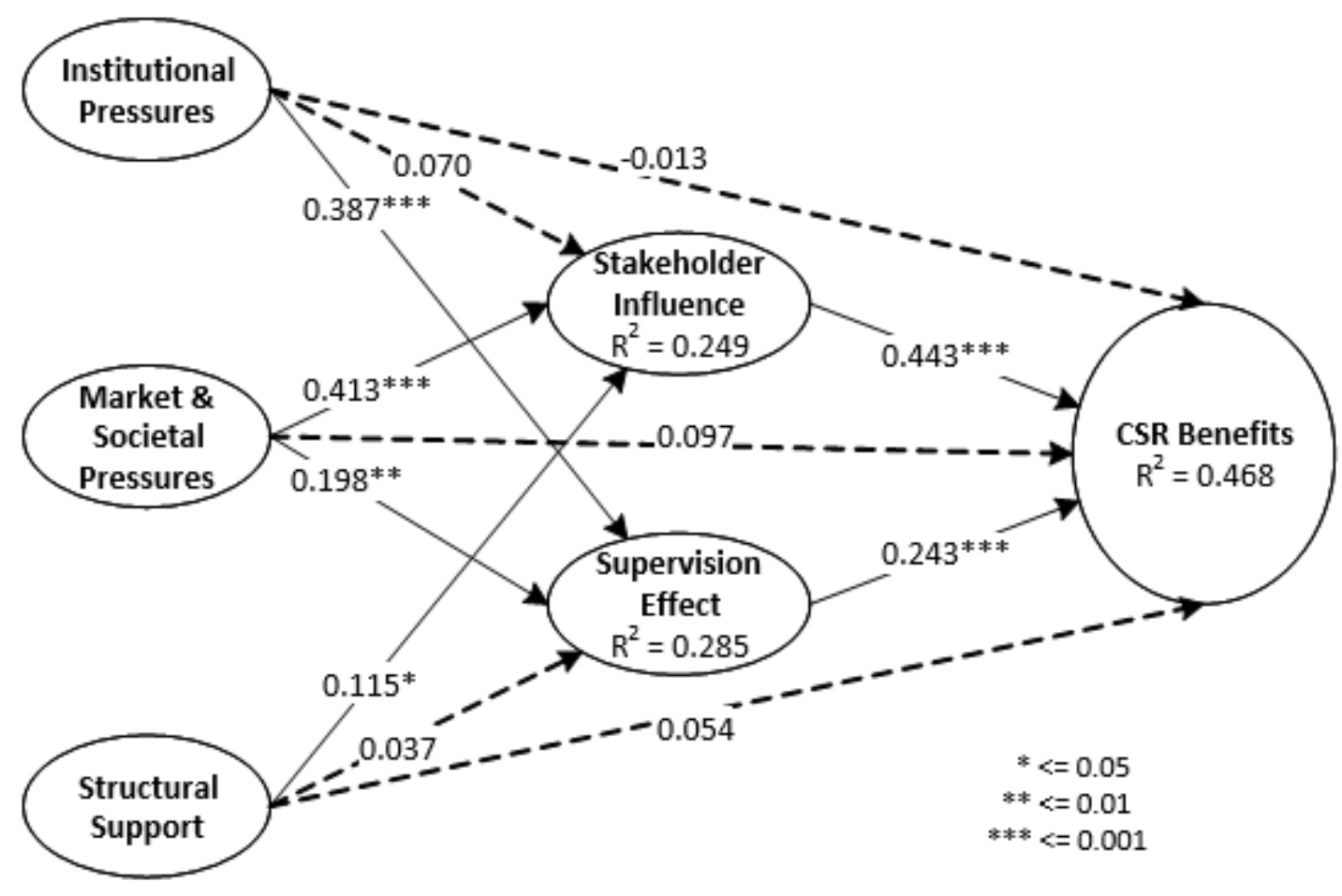

Figure 2. Overall Model Results with Direct Effects Included

Note: Dotted lines indicate non-significant relationships

Source: Compiled by authors

Mediation tests were conducted to test the mediation hypotheses $\mathrm{H} 9$ to H11. Because our model has more than one mediating variable, we followed the procedures recommended by Hair et al. (2017) to analyze multiple mediations and interpret the results. Table 6 summarizes the results of the mediation tests and provides interpretations of the indirect effects of the exogenous variables on the dependent variable. In the presence of the two mediating variables - stakeholder influence and supervision effect - the indirect influence of each exogenous variable on CSR benefits actually differ. For institutional pressures, it is found that supervision, rather than stakeholder influence, fully mediates the effect of institutional pressures on CSR benefits. This means that the impact of institutional pressures on CSR benefits is due to its effect on supervision and not due to its effect on stakeholder influence. This result tends to support our earlier prediction that supervision is more important than promotion, i.e., that action is more influential than words. For market and societal pressures, it is found that both stakeholder influence and supervision fully mediate the effect of market and societal pressures on CSR benefits. In other words, the impact of market and societal pressures on CSR benefits is due to its support of both stakeholder influence and supervision. Although the indirect effects of market and societal pressures are significant through both mediators, its effect is stronger through stakeholder influence $(0.183)$ than through supervision (0.094). For structural support, it is found that stakeholder influence, rather than supervision, fully mediates the effect of structural support on CSR benefits. This means that the impact of structural support on CSR benefits is due to its effect on stakeholder influence and not due to its effect on supervision. The finding that the indirect effects of both market and societal pressures and structural support are more strongly mediated through stakeholder influence than through supervision is counterintuitive to our earlier prediction that action is more influential than words. Perhaps both actions and words need to work together to influence CSR.

Thus, for the mediation hypotheses, $\mathrm{H} 9$ and $\mathrm{H} 11$ are partially supported and $\mathrm{H} 10$ is fully supported. Table 7 summarizes the hypotheses results for hypotheses H1 through H11. 
Table 6. Mediation Test Results

\begin{tabular}{|c|c|c|c|c|}
\hline Variable & Effect & $t$-Value & $\begin{array}{c}\text { Significant } \\
\text { at } p<= \\
0.05 ?\end{array}$ & Interpretation \\
\hline \multicolumn{5}{|l|}{ Direct Effects: } \\
\hline Institutional Pressures --> Stakeholder Influence & 0.070 & 1.023 & No & \\
\hline Market \& Societal Pressures --> Stakeholder Influence & 0.413 & 5.795 & Yes & \\
\hline Structural Support --> Stakeholder Influence & 0.115 & 2.230 & Yes & \\
\hline Institutional Pressures --> Supervision Effect & 0.387 & 5.666 & Yes & \\
\hline Market \& Societal Pressures --> Supervision Effect & 0.198 & 2.693 & Yes & \\
\hline Structural Support --> Supervision Effect & 0.037 & 0.764 & No & \\
\hline Institutional Pressures --> CSR Benefits & -0.013 & 0.198 & No & \\
\hline Market \& Societal Pressures --> CSR Benefits & 0.097 & 1.600 & No & \\
\hline Structural Support --> CSR Benefits & 0.054 & 1.184 & No & \\
\hline Stakeholder Influence --> CSR Benefits & 0.443 & 6.344 & Yes & \\
\hline Supervision Effect --> CSR Benefits & 0.243 & 3.194 & Yes & \\
\hline \multicolumn{5}{|l|}{ Indirect Effects: } \\
\hline Institutional Pressures --> Stakeholder Influence --> CSR Benefits & 0.031 & 1.003 & No & no mediation \\
\hline Market \& Societal Pressures --> Stakeholder Influence --> CSR Benefits & 0.183 & 4.159 & Yes & full mediation \\
\hline Structural Support --> Stakeholder Influence --> CSR Benefits & 0.051 & 2.079 & Yes & full mediation \\
\hline Institutional Pressures --> Supervision Effect --> CSR Benefits & 0.094 & 2.946 & Yes & full mediation \\
\hline Market \& Societal Pressures --> Supervision Effect --> CSR Benefits & 0.048 & 1.958 & Yes & full mediation \\
\hline Structural Support --> Supervision Effect --> CSR Benefits & 0.009 & 0.722 & No & no mediation \\
\hline
\end{tabular}

Source: Compiled by authors

Table 7. Summary of Hypotheses Results

\begin{tabular}{|l|l|}
\hline \multicolumn{1}{|c|}{ Hypotheses H1-H8 } & \multicolumn{1}{|c|}{ Result } \\
\hline H1: Institutional Pressure is positively associated with Stakeholder Influence. & Not supported \\
\hline H2: Institutional Pressure is positively associated with Supervision Effect. & Supported \\
\hline H3: Market \& Societal Pressure is positively associated with Stakeholder Influence. & Supported \\
\hline H4: Market \& Societal Pressure is positively associated with Supervision Effect. & Supported \\
\hline H5: Structural Support is positively associated with Stakeholder Influence. & Supported \\
\hline H6: Structural Support is positively associated with Supervision Effect. & Not supported \\
\hline H7: Stakeholder Influence is positively associated with CSR Benefits. & Supported \\
\hline H8: Supervision Effect is positively associated with CSR Benefits. & Supported \\
\hline \multicolumn{1}{|c|}{ Mediation Hypotheses H9-11 } & \multicolumn{1}{c|}{ Result } \\
\hline $\begin{array}{l}\text { H9: The association between Institutional Pressures and CSR Benefits will be at least } \\
\text { partially mediated by Stakeholder Influence and Supervision. }\end{array}$ & $\begin{array}{l}\text { Supported for Supervision Effect, but } \\
\text { not Stakeholder Influence }\end{array}$ \\
\hline $\begin{array}{l}\text { H10: The association between Market \& Societal Pressures and CSR Benefits will be at } \\
\text { least partially mediated by Stakeholder Influence and Supervision. }\end{array}$ & $\begin{array}{l}\text { Supported for } \\
\text { Influence and Supervision Effect }\end{array}$ \\
\hline $\begin{array}{l}\text { H11: The association between Structural Support and CSR Benefits will be at least } \\
\text { partially mediated by Stakeholder Influence and Supervision. }\end{array}$ & $\begin{array}{l}\text { Supported for Stakeholder Influence, but } \\
\text { not Supervision Effect }\end{array}$ \\
\hline
\end{tabular}

Source: Compiled by authors

\section{Discussion}

Mixed findings in extant literature suggest that the relationship between drivers of CSR and CSR may not be direct and that the relationships may be more nuanced. Our study set out to identify effective mediators between CSR drivers and CSR benefits. Specifically, the study addressed two research questions: 1) Do institutional pressures, market and societal pressures, and structural supports have a significant effect on stakeholders and their supervision for determining CSR benefits? And 2) Do stakeholders and their supervision have a significant mediating effect on CSR benefits?

For the first research question, it was found that institutional pressures, market and societal pressures, and structural supports do have significant effects on stakeholders and their supervision, but to differing degrees. The three together explain approximately the same degree of variance in stakeholder influence as well as supervision, but market and societal pressures are strongly related to both stakeholder influence and supervision. While institutional pressures are strongly related to supervision, but unrelated to stakeholder influence, structural support is found to be the reverse. Structural support is related to stakeholder influence, but unrelated to supervision.

For the second research question, it was found that both stakeholder influence and supervision mediate the effects of institutional pressures, market and societal pressures, and structural supports on CSR benefits. Both stakeholder influence and supervision are directly related to CSR benefits and their relationships are highly significant while the direct relationships between institutional pressures, market and societal pressures, and structural supports and CSR benefits, as illustrated in Figure 2, are non-significant in the presence of the two 
mediators. This indicates that the mediators are proximal factors related to CSR benefits while the three exogenous variables are distal factors. Further, mediation analyses confirm that the effects of institutional pressures, market and societal pressures, and structural supports on CSR benefits are more or less mediated through stakeholder influence and supervision. The effect of market and societal pressures is fully mediated via both stakeholder influence and supervision. However, the effect of institutional pressures is only mediated through supervision and not through stakeholder influence, while the effect of structural support is only mediated through stakeholder influence and not through supervision. These findings suggest that perhaps both actions (supervision) and words (stakeholder influence) are needed as they work together to influence CSR as discussed earlier in the mediation analysis section. Our speculation that the mediating effect of supervision should be stronger than the mediating effect of stakeholder influence is, therefore, not totally supported by this research study.

Taken together, the findings tend to support Kurbjeweit's (2011) theory suggesting that regulations and other pressures do not sustain the orderly function of society without ethical business actors, which in our case reflect the mediator effect of stakeholder influence and supervision in this study.

\section{Conclusion}

As our society and business are getting more and more complicated due to the advancement of technology and multi-dimensional relationship, the realization of CSR becomes elusive. This research study attempted to understand the mediation effect of stakeholder influence and supervision on CSR. While stakeholder influence is the ideological and subtle effect, supervision represents the concrete action for CSR. Based on the analysis outcome, we can answer the question of why the same kind of institutional pressures, market and societal pressures, or structural support does not lead to similar CSR benefits. The answer rests on the mediation effect of stakeholder influence and supervision. Without the mediation effect of stakeholder influence and supervision, the exogenous factors do not lead to the desirable CSR benefits. However, an interesting finding is the differential effect between stakeholder influence and supervision on CSR benefits. The analysis results do not support our prediction that deeds (supervision) have a stronger effect than words (stakeholder influence). On the contrary, words (0.443) have a much stronger effect than deeds (0.243) on CSR benefits.

We have a few interesting conclusion remarks from this research study. First, while both words (stakeholder influence) and deeds (supervision effect) are significant drivers for CSR benefits, words (0.443) have a stronger effect than deeds (0.243). Words and deeds probably affect each other leading to the final outcome of CSR. If the stakeholders repeatedly insist on CSR, it will have a positive effect. Conducive supervision action for CSR will also have a positive effect. It is an interesting study in the future how words and deeds can be combined in the CSR process to generate the optimal benefit outcome. Second, spending resources on generating stakeholder influence and supervision effect can be more significant for CSR than lobbying for external pressure and structural support. Future studies are needed to confirm that human effect from business ethics actors is more significant than the non-human effect from institution, society, market, or structure on CSR. Third, the two strongest relationships from exogenous factors to endogenous factors are market/societal pressures to stakeholder influence (0.413) and institutional pressures to supervision effect (0.387). If we understand different pressure as a stick and structural support as carrot, the data support that stick is a better tool than carrot for effecting CSR. This finding needs further studies to verify.

This study has the following limitations. First, there is only one respondent from each company to provide the survey data. Depending on the respondent's position and management level, the input can be different leading to different conclusions. Second, the sample size and variety can be enlarged to enhance the reliability and validity of the analyses. Third, the concept of stakeholders may be too broad as different categories of stakeholders can fine-tune the conceptual model for future studies. Despite these limitations, we believe that this study offers a unique perspective to help untangle the relationships among external pressures, structural support, and CSR benefits.

\section{References}

1. Ajina, A., Lakhal, F., \& Ayed, S. (2019). Does corporate social responsibility reduce earnings management? The moderating role of corporate governance and ownership. Management International, 23(2), 45-55, 147, 150, 153-154. https://doi.org/10.7202/1060030ar.

2. Ankur, Roy \& Vishal (2013). SMEs Motivation: Corporate social responsibility. SCMS Journal of Indian Management, 01, 11-21. Available at: https://www.scms.edu.in/journal/.

3. Atherton, S. C., Blodgett, M. S., \& Atherton, X. A. (2011). Fiduciary Principles: corporate responsibilities to stakeholders. Journal of Religion and Business Ethics, 2(2), 1-15. Available at: https://via.library.depaul.edu/jrbe/. 
4. Aya Pastrana, N., \& Sriramesh, K. (2014). Corporate social responsibility: perceptions and practices among SMEs in Colombia. Public Relations Review, 40(1), 14-24. https://doi.org/10.1016/j.pubrev.2013.10.002.

5. Bice, S. (2017). Corporate social responsibility as an institution: A social mechanisms framework. Journal of Business Ethics, 143(1), 17-34. https://doi.org/10.1007/s10551-015-2791-1.

6. Brekke, K. A., \& Nyborg, K. (2005). Moral hazard and moral motivation: Corporate social responsibility as labour market screening. St. Louis: Federal Reserve Bank of St Louis. Retrieved from http://vortex3.uco.edu/login?url=https://search-proquest-com.vortex3.uco.edu/docview/1698480942?accountid=14516.

7. Burt, E., \& Mansell, S. (2019). Moral agency in charities and business corporations: exploring the constraints of law and regulation. Journal of Business Ethics, 159, 59-73. https://doi.org/10.1007/s10551-017-3750-9.

8. Camilleri, M. A. (2017). Corporate sustainability and responsibility: creating value for business, society and the environment. Asian Journal of Sustainability and Social Responsibility, 2, 59-74. https://doi.org/10.1186/s41180-017-0016-5.

9. Carroll, A. R., \& Shabana, K. M. (2010). The business case for corporate social responsibility: a review of concepts, research and practice. International Journal of Management Review, 12(1), 85-105. https://doi.org/10.1111/j.1468-2370.2009.00275.x.

10.Chin, W. W. (1998). The partial least squares approach for structural equation modelling. Ed. G. A. Marcoulides. Modern Methods for Business Research, 295-336. Lawrence Erlbaum Associates: Mahwah, NJ. Available at: https://www.questia.com/library/95678668/modern-methods-for-business-research.

11.Chunfang, Y. (2009). Research on the Driving Mechanism of Corporate Social Responsibility. A thesis submitted in fulfilment of the requirements for the degree of Doctor of Philosophy, Huazhong University of Science and Technology. Available at: https://www.proquest.com/products-services/pqdtglobal.html.

12.ECLAC (2008). Promoting Corporate Social Responsibility in Small and Medium Enterprises in the Caribbean: Survey Results. ECLAC Liaison Office in Washington, D.C. Available at: https://www.cepal.org/en/publications/list? search_fulltext=promoting\%20corporate\%20social\%20responsibility.

13.Fanghui, J., \& Ziyuan, X. (2005). The implementation of corporate social responsibility based on consumer choice. China Industrial Economics, 210(9), 91-98. Available at: https://www.oriprobe.com/journals/zggyjj.html.

14.Fornell, C., and Larcker, D. F. (1981). Evaluating structural equation models with unobservable variables and measurement error. Journal of Marketing Research, 18(1), 39-50. https://doi.org/10.1177/002224378101800104.

15.Freeman, R. E. (1984). Strategic Management: A Stakeholder Approach. Boston: Pitman Publishing. Available at: https://www.amazon.com/Strategic-Management-R-Edward-Freeman/dp/0521151740.

16.Garas, S., \& ElMassah, S. (2018). Corporate governance and corporate social responsibility disclosures. Critical Perspectives on International Business, 14(1), 2-26. https://doi.org/10.1108/cpoib-10-2016-0042.

17.Hair, J. F., Black, W. C., Babin, B. J., and Anderson, R. E. (2014). Multivariate Data Analysis, 7th ed. Pearson New International Edition. Pearson Education Limited. Available at: https://is.muni.cz/el/1423/podzim2017/PSY028/um/_Hair_-_Multivariate_data_analysis_7th_revised.pdf.

18.Hair, J., Hult, G. T. M., Ringle, C. M., and Sarstedt, M. (2017). A Primer on Partial Least Squares Structural Equation Modeling (PLS-SEM), 2nd ed. SAGE Publications: Los Angeles. https://doi.org/10.15358/9783800653614.

19.Henseler, J., Ringle, C. M., and Sinkovics, R. R. (2015). The use of partial least squares path modelling in international marketing. Advances in International Marketing, 20, 277-320. https://doi.org/10.1108/S1474-7979(2009)0000020014.

20.Hongling, G. (2006). The Relevance of Corporate Social Responsibility Supply and Financial Performance based on Consumer Demand Supply. A thesis submitted in fulfilment of the requirements for the degree of Doctor of Philosophy, Southwest Jiaotong University. Available at: https://www.proquest.com/productsservices/pqdtglobal.html.

21.Jackson, G., Bartosch, J., Avetisyan, E., Kinderman, D., \& Jette, S. K. (2019). Mandatory non-financial disclosure and its influence on CSR: An international comparison. Journal of Business Ethics, 159, 1-20. https://doi.org/10.1007/s10551-019-04200-0.

22.José-Luis Godos-Díez, Cabeza-García, L., Alonso-Martínez, D., \& Fernández-Gago, R. (2018). Factors influencing board of directors' decision-making process as determinants of CSR engagement. Review of Managerial Science, 12(1), 229-253. https://doi.org/10.1007/s11846-016-0220-1.

23.Katmon, N., Zam, Z. M., Norlia, M. N., \& Farooque, O. A. (2019). Comprehensive board diversity and quality of corporate social responsibility disclosure: Evidence from an emerging market. Journal of Business Ethics, 157(2), 447-481. https://doi.org/10.1007/s10551-017-3672-6.

24.Kurbjeweit, B. H. (2011). The relationship between ethics and law in governing the game of business. Journal of Business Ethics Education, 8, 55-62. Available at: https://www.neilsonjournals.com/JBEE/. 
25.Lindell, M. K., and Whitney, D. J. (2001). Accounting for common method variance in cross-sectional research designs. Journal of Applied Psychology, 86(1), 114-121.

https://doi.org/10.1037/0021-9010.86.1.114.

26.Lisi, I. E. (2018). Determinants and performance effects of social performance measurement systems. Journal of Business Ethics, 152(1), 225-251. https://doi.org/10.1007/s10551-016-3287-3.

27.McKinley, Andrew. (2008). The Drivers and Performance of Corporate Environmental and Social Responsibility in the Canadian Mining Industry. A thesis submitted in fulfilment of the requirements for the degree of Master of Geography, University of Toronto. Available at: https://www.proquest.com/productsservices/pqdtglobal.html.

28.Mzembe, A., N., \& Meaton, J. (2014). Driving corporate social responsibility in the Malawian mining industry: a stakeholder perspective. Corporate Social Responsibility and Environmental Management, 21(4), 189-201. https://doi.org/10.1002/csr.1319.

29.Pavlou, P. A., Liang, H., and Xue, Y. (2007). Understanding and mitigating uncertainty in online exchange relationships: A principal-agent perspective. MIS Quarterly, 31(1), 105-136. https://doi.org/10.2307/25148783.

30.Ringle, C. M., Wende, S., and Becker, J. M. (2014). SmartPLS 3. Hamburg: SmartPLS. Retrieved from http://www.smartpls.com.

31.Roy, A., Vigao, V., \& Jain, P. (2013). SME motivation: corporate social responsibility. SCMS Journal of Indian Management, 10(1), 11-21. Available at: https://www.scms.edu.in/journal/.

32.Sanchez, R. G., \& Bolivar, M. P. (2017). Perception of stakeholder pressure for supply-chain social responsibility and information disclosure by state-owned enterprises. The International Journal of Logistics Management, 28(4), 1027-1053. https://doi.org/10.1108/IJLM-05-2016-0118.

33.Schwartz, M. S., \& Carroll, A. B. (2003). Corporate social responsibility: a three-domain approach. Business Ethics Quarterly, 13(4), 503-530. https://doi.org/10.5840/beq200313435.

34.Sethi, S. P., Martell, T. F., \& Demir, M. (2017). Enhancing the role and effectiveness of corporate social responsibility (CSR) reports: The missing element of content verification and integrity assurance. Journal of Business Ethics, 144(1), 59-82. https://doi.org/10.1007/s10551-015-2862-3.

35.Shubham, Charan, P., \& Murty, L. S. (2018). Institutional pressure and the implementation of corporate environment practices: Examining the mediating role of absorptive capacity. Journal of Knowledge Management, 22(7), 1591-1613. https://doi.org/10.1108/JKM-12-2016-0531.

36.Smolennikov, D., \& Kostyuchenko, N. (2017). The role of stakeholders in implementing corporate social and environmental responsibility. Business Ethics and Leadership, 1(1), 55-62. https://doi.org/10.21272/bel.2017.1-07.

37.Susan, L., Y., Mona, V., M. (2014). Firms' corporate social responsibility behaviour: an integration of institutional and profit maximization approaches. Journal of International Business Studies, 45, 670-698. https://doi.org/10.1057/jibs.2014.29.

38.Taisong, S. Q. (2013). Driving mechanism of institutional environment on corporate social responsibility based on the analysis of cases. Studies in Dialectics of Nature, 28(2), 113-119. Available at: https://www.oriprobe.com/journals/zrbzfyj.html.

39. The International Organization for Standardization. (2010). ISO 26000:2010 Guidance on Social Responsibility. American National Standards Institute. Available at: https://www.iso.org/standard/42546.html.

40.Vashchenko, M. (2017). An external perspective on CSR: what matters and what does not? Business Ethics: A European Review, 26, 396-412. https://doi.org/10.1111/beer.12162.

41.Wang, L. \& Liang, X. (2017). Profit or legitimacy? What drives firms to prioritize social stakeholders? Asian Journal of Business Ethics, 6, 57-79. https://doi.org/10.1007/s13520-016-0072-4.

42.Wayne, V., \& Chad, K. (2015). Integrated value creation (IVC): beyond corporate social responsibility (CSR) and creating shared value (CSV). Journal of International Business Ethics, 1, 29-43. Available at: http://www.cibe.org.cn/en/page/Default.asp?pageID=81.

43. Yibo, R. (2007). A survey on corporate social responsibility in seven countries - a survey report from the Society for Human Resources Management (SHRM). China WTO Tribune, 5, 66-68. Available at: https://www.shrm.org/hr-today/trends-and-forecasting/research-andsurveys/Documents/2007\%20Corporate\%20Social\%20Responsibility\%20Pilot\%20Study.pdf.

44.Zhao, X., Chen, S., \& Xiong, C. (2016). Organizational attention to corporate social responsibility and corporate social performance: the moderating effects of corporate governance. Business Ethics: A European Review, 25(4), 386-399. https://doi.org/10.1111/beer.12124.

45. Zhilong, T., \& Yuanqiong, H. (2005). Research on non-market strategy and action of enterprise in China. China Industrial Economics, 9, 82-90. Available at: https://www.oriprobe.com/journals/zggyjj.html. 